\title{
Verification of Psychodiagnostic Capabilities of Handwritten Texts ${ }^{*}$
}

\section{Верифікація психодіагностичних можливостей рукописних текстів}

\author{
Vitalii Bochelyuk ${ }^{1}$ \\ Dr. in Psychology, Professor, \\ Head of the Department \\ of Psychology
}

\author{
Віталій Бочелюк ${ }^{1}$ \\ доктор психологічних наук, \\ професор, \\ завідувач кафедри психології
}

E-mail: vitalik.psyhol@ukr.net orcid.org/0000-0001-8727-3818

Nikita Panov ${ }^{2}$ Ph.D. in Psychology, Assistant Professor
Микита Панов 2

кандидат психологічних наук, доцент

E-mail: nikita.psyhol@ukr.net orcid.org/0000-0002-5085-8895

\section{Valentyna Zaytseva ${ }^{1}$}

Ph.D. in Pedagogy, Professor, Head of the Department of Tourism, Director of the Institute of Management and Law
Валентина Зайцева ${ }^{1}$ кандидат педагогічних наук, професор, завідувач кафедри туризму, директор інституту управління та права

E-mail: valentz181@gmail.com orcid.org/0000-0003-1526-2292

* This research was funded by the Ministry of Education and Science of Ukraine, RN 0118U100315, «Modeling and Practical Support for the Development of Professionalism Components».

** Дослідження виконане за фінансової підтримки Міністерства освіти і науки України, Реєстраційний номер 0118U100315, «Моделювання та практичне забезпечення розвитку складових професіоналізму». 
1 Zaporizhzhya National

Technical University

64, Zhukovsky Str., Zaporozhye, Ukraine, 69063
1 Запорізький національний технічний університет $\triangle$ вул. Жуковського, 64, м. Запоріжжя, Україна, 69063

${ }^{2}$ КВНЗ «Хортицьька національна навчально-реабілітаційна академія» 3ОР

$\triangle$ вул. Наукове містечко

(о. Хортиця), 59, м. Запоріжжя, Україна, 69017

Original manuscript received March 04, 2019

Revised manuscript accepted October 15, 2019

\begin{abstract}
Introduction. The research paper contains a critical analysis of the graphological approach to the study of handwritten texts. The problem statement is justified by a special way of the formation of domestic psychology, which has been isolated for a long time from world tendencies. Although the study of manuscripts is not a widespread practice, graphological analysis is recognized at the highest academic level, including in the field of legal proceedings. The aim of the study is to test empirically the diagnostic potential of handwriting as a product of linguistic activity of an individual.
\end{abstract}

Research Procedure. The object of empirical testing is the left-hand slope as a deviation from the usual way of writing. The data on variability of the variable in the sample of 119 students were collected; three study groups were selected on the basis of clusterization: with left-handed, direct-handed and right-handed writing.

Results. The interpretations of the left-hand slope in graphology manuals are studied, and the lack of the evolution is shown. It was find out that the descriptions are philosophizing around previously published texts with the addition of details, author's own associations; herewith the characteristics of the handwriting are anthropomorphized and directly transferred to the characteristics of personality. A questionnaire has been developed to verify the effect of personal validation. With regard to $40 \%$ of the statements of the questionnaire, all respondents expressed a positive opinion; these formulations do not differentiate the respondents and do not have any diagnostic value. None of the graphological interpretations of the lefthand slope was really more expressive in the left-handwriting group. According to the indicators of K. Riff's Scale of Psychological Well-being, two cases of statistically significant difference between groups with different handwriting were found: the scales of "Environmental management» and "Balance of affect». The obtained results lead to 
the idea that handwriting concentrates, to a certain extent, personal characteristics of the author and is an informative psychological feature - but this interpretation must be confirmed by the data of the psycholinguistic method. In general, the research paper demonstrates that handwriting can be the subject of scientific research, to which methodological procedures recognized in modern psychology are applied.

Key words: graphology, psycholinguistic analysis of handwriting, linguistic personality, personal validation.

\section{Вступ}

У сучасній психолінгвістиці активно розвивається науковий напрям, тісно пов'язаний з вивченням зовнішньої, графічної складової письмового мовлення - графічна або почеркознавча експертиза аналіз почерка, орфографії, розміщення тексту та сторінці та інших зовнішніх ознак тексту. Суть психолінгвістичної почеркознавчої експертизи полягає в тому, щоб на основі дослідження формальних (лінгвістичних, текстових, фонетичних, стилістичних тощо) i неформальних (змістовних, смислових, інтенціональних та ін.) характеристик тексту визначити, по-перше, психологічні й індивідуальні риси автора тексту; по-друге, категоріальні ознаки суб'єкта мовлення - вік, стать, приналежність до тієї чи іншої соціальної групи, рідну мову, походження з того чи іншого регіону тощо (Леонтьев, 1999). Так, М.В. Новікова-Грунд довела можливість визначення в писемному мовленні базових смислів, картини світу людини (Новикова-Грунд, 2006). Н.О. Фоміна розробила наукову концепцію цілісного аналізу прояву властивостей особистості в тексті як продукті мовленнєвої діяльності. Вченою представлена авторська методика полікомпонентного аналізу тексту, яка дає можливість розглядати не тільки його власне лінгвістичні (мовні, мовленнєві й змістовно-смислові) характеристики, а й відображення в тексті психологічних (мотиваційно-цільових, когнітивних, динамічних, емоційних, регулятивних) властивостей автора тексту. Науковцем доведено, що репрезентація властивостей мовленнєвої особистості відбувається через використання певних засобів для вираження думок, бажань, емоцій, почуттів, регуляції поведінки та спілкування (Фомина, 2018). В рамках наукової школи Н.О. Фоміної досліджені різноманітні прояви в тексті, як-от: домінування першої 
або другої сигнальної системи (Фомина \& Мирчетич, 2013), мотиваційна спрямованість, емоційна виразність та саморегуляція (Фомина \& Леева, 2013); відповідальність (Фомина \& Орлов, 2017), товариськість (Фомина, 2018). Українськими дослідниками розроблені практичні способи фіксації психічних станів людини у письмовій продукції, зокрема: діагностика душевного страждання (Волкова, 2014), вербальні прояви тривожності (Турчак, 2015). Виявлені лінгвістичні предиктори здоров'я, слова-маркери соматичних захворювань (Максименко \& Орап, 2018).

Отже, мета статmі - представити результати верифікації психолінгводіагностичних можливостей рукописних текстів.

\section{Методи дослідження}

3 метою проведення дослідження використовувався комплекс методів, як-от: теоретичні (аналіз наукових джерел, узагальнення проаналізованої літератури та тї систематизація, виокремлення базових положень, на яких грунтується дослідження, формулювання висновків); емпіричні (графічний аналіз, письмове анкетування); статистична обробка отриманих результатів (підрахунки здійснювались в програмі SPSS 16.0).

\section{Результати теоретичного дослідження}

Традиційно зв'язок між почерком та індивідуальними емоційно-психічними й фізіологічними особливостями людини є предметом вивчення графології (за деякими джерелами графеметрія (graphemetrics)). Для вивчення вираження характеру й здібностей особистості, яка написала текст, графологія використовує як технічні інформативні ознаки (швидкість і натиск письма, округлість, величина, з'єднаність, нахил, розмах, різниця висот великих та малих літер, стиль написання окремих знаків тощо), так і лінгвістичні - система й граматологія письма (змістова складова письма). Попри дискусійність змісту терміну «графологія» (який традиційно асоціюється 3 «визначенням характеру людини через візуальні технічні ознаки почерку» (Encyclopedia Britannica, 2011)), теоретичних засад цього наукового напряму (за деякими 
джерелами це лише «проективна техніка»), розуміння первинності між технічними та лінгвістичними аспектами письма, цей термін («графологія») у студійованих нами наукових джерелах переважно інтерпретується як «лінгвістичний рівень аналізу, що вивчає графічні аспекти мови, беручи до уваги їі стилістику та мультимодальність» (Gómez-Jiménez, 2015; Nkopuruk, 2018). Незважаючи на зазначене вище, будь-яка дискусія щодо графології повинна, на наше переконання, відштовхуватися та спиратися на науковий доробок Едварда Левентсона (Levenston, 1992) та Джона Леннарда (Lennard, 1996), оскільки вони запропонували грунтовний та конкретний підхід до ідентифікації писемності не лише як певного способу спілкування через візуалізовані графічні символи, який притаманний певним психотипам особистості, але й як певного лінгвістичностилістичного феномену, завдяки якому перші систематично та структуровано організовуються комунікатором у повідомлення 3 вимірюваними характеристиками, як-от: володіння тактикою переконання, рефлексія, емоційність, уподобання, інтуїція, емпатія, конформізм, само-контроль дотримання соціально-комунікативних норм, зразків поведінки, соціальних ролей тощо.

Вибух популярності графологічний ідей відбувся всередині минулого століття, коли в різних країнах світу був опублікований ряд авторитетних керівництв щодо персональної діагностики на основі власноручних дописів: «Почерк та особистість» Д.М. ЗуєваІнсарова (Зуев-Инсаров, 1992), «Довідник 3 графології» Г. Ренда (Rand, 1947), «Аналіз рукописного тексту як психодіагностичний інструмент: дослідження в загальній та клінічній графології» У. Зоннемана (Sonnemann, 1950) та багатьох інших. У той час на аналіз почерку покладалися великі сподівання. В огляді «Психології здорового глузду», поширеної в американському суспільстві, A. Roback (1939) оцінює графологію як цікаву та перспективну теорію. У передмові книги У. Зоннемана відзначено: «Графологія має зайняти належне місце серед методів діагностики особистості, нарівні 3 іншими проективними тестами (як тест Роршаха), що витримали перевірку часом» (Sonnemann, 1950). Але перевірка часом мала неоднозначні результати.

У США графологічний аналіз активно застосовувався в багатьох професійних сферах, але в 90-х роках цей напрямок був дискредитований. Суспільне розчарування наочно відображене в 
науково-популярному серіалі «Веyond Science?», окремий випуск якого (Beyond Science?, 1997) був присвячений розвінчуванню графологічних діагнозів (на прикладі компанії Datagraph, що на той момент налічувала десятки тисяч графологів по всій країні; вони використовували 420 вимірювань, які об'єднували в профіль особистості по 14 характеристикам, від самоповаги до потенціалу продажів). В цей час були опубліковані результати низки критичних досліджень, що спростовували практичну достовірність графологічного аналізу. Експерименти (див. Ben-Shakhar, BarHillel, Bilu, Ben-Abba \& Flug, 1986) показали, що графологічні прогнози кар'єрної успішності (так само як і оцінки рукописних біографій співробітників, зроблені клінічними психологами за традиційними підходами), не корелюють 3 реальними оцінками роботодавців. Дослідження демонстрували, що графологічні описи особистісних рис не більш ефективні, ніж випадкові моделі або описи, зроблені неспеціалістами (Rafaeli \& Klimoski, 1983; BenShakhar et al., 1986). Учені (King \& Koehler, 2000) за допомогою сфабрикованих особистісних профілів довели ілюзорність кореляцій у графологічних висновках. У підсумку графологія була оголошена протонауковим та псевдонауковим вченням, про що сьогодні легко дізнатися з Вікіпедії.

У західній Свропі ставлення до графології відносно прихильне та врівноважене. Активно працюють національні спільноти графологів, проводяться фахові конференції, ця спеціальність викладається у декількох вишах Іспанії та Німеччини. Суспільний інтерес підтримується тим, що аналіз мотиваційних есе та автобіографій, написаних власноруч, широко використовується в кадровому відборі (Steiner \& Gilliland, 1996).

A. Jansen (1973) опублікував одне 3 найбільш грунтовних i поміркованих досліджень, присвячених пошуку наукового базису графології. Впродовж семи років більше 8 тисяч суджень графологів i контрольних груп були перевірені за зовнішніми критеріями та по відношенню один до одного. Встановлено, що при оцінці рукописів результати досвідчених графологів не відрізняються від висновків клінічних психологів або фахівців в області психодіагностики. Існують позитивні, але слабкі кореляції між графологічними судженнями та даними психологічних вимірювань, а також рейтингами роботодавців. Зафіксована низька надійність 
графологічного аналізу: дані різних фахівців не погоджуються між собою, навіть повторне тестування досвідченим графологом показує відмінні результати. Цікаво, що при однаковому матеріалі більш діагностично цінні висновки давали психологи, які використовували інший метод оцінки (психолінгвістичний аналіз тексту). Отже, хоча на рівні великих узагальнень графологічні судження частіше вірні, ніж невірні, для оцінки особистості графологія є сумнівним діагностичним методом 3 мінімальним практичним значенням (Jansen, 1973). На думку вченого, вона не має виступати основою для негайних (кадрових) рішень. Але графологія корисна як проективний метод - для висування гіпотез, які у випадку підтвердження іншими методиками є практично цінними. Це так званий метод «широкої смуги»: тест охоплює велику область, в межах якої пропонує певні моменти, які повинні бути досліджені більш надійними інструментами, але сам тест ніколи не повинен використовуватися як основа для рішень або прогнозів, оскільки його валідність в порівнянні 3 практичними критеріями занизька (слід відзначити що в цьому графологія виступає в одному ряду 3 відомими клінічними методами, наприклад, тестом Роршаха).

В окремих випадках, зумовлених обмеженістю інших джерел інформації застосування графологічного аналізу дійсно $є$ доречним (наприклад при ретроспективному аналізі історичних постатей або дистантній діагностиці). Тоді вивчення почерку варто поєднати 3 психолінгвістичним аналізом тексту, оскільки попередні дослідження показали, що кожна людина використовує унікальне поєднання мовних атрибутів (тобто граматику, синтаксис, орфографію, лексику та фразеологію) як в усному, так і у писемному мовленні (Juola, 2006; McMenamin, 2002; Van Halteren et al., 2005). У розрізі зазначеного, дане дослідженні не $є$ абстрагованим від застосування мультимодальності, яка нещодавно стала корисним доповненням теоретичної системи графології, оскільки доповнює ii інструментарій для аналізу візуальних аспектів мови й допомагає вирішенню певних питань щодо поліпшення розуміння певних графологічних iii аспектів, а саме таких як: системи письма (Kress \& Leeuwen, 1996: 55-57), розподіл (організацію) елементів письма (Lennard, 2005; Kress \& Leeuwen, 1996: 59), пунктуацію (Leventson, 1992), правопис (Leventson, 1992; Kress \& Van Leeuwen, 1996: 18-21, 58), шрифт та колір (Lennard, 2005; Leventson, 1992; 
Van Leeuwen \& Jewitt, 2001: 167-171), та лексико-граматичну й синтаксичну наповненість (Wright, 2014; Jakovljev \& Milin, 2017). Отже, психолінгвістичний аналіз тексту базується на розумінні, що змістова і рухова сторони письменного мовлення $\epsilon$ нерозривно поєднаними. Це втілюється у наступній залежності: певний рівень грамотності відповідає відповідному рівню координації рухів; зміст і цілі рукописного (письма) тексту визначають типографію почерку; особливості психічного стану особи впливають на його/ iii рухову сторону писемного мовлення і демонструють іiі (особи) інтелектуальну сторону.

Вітчизняні психологи залишалися осторонь цих процесів. В СРСР ця діяльність була заборонена, тож після його розпаду відбувся своєрідний «ренесанс» графології: книжкові полиці наповнюються публікаціями 3 тлумачення почерку; захищаються дисертації, що демонструють дієвість графологічного аналізу в дослідженні особистості (Смыслов, 1999; Осекова, 2003), напрямок отримує послідовників у бізнес-середовищі та науковій еліті. Почерк розглядається як форма антропологічного існування людини, при цьому за ним «уловлюються такі смисли, засобів для виявлення яких в європейській культурі досить небагато» (Кравченко, 2016). Сучасні графологи намагаються стандартизувати процес аналізу, залучивши до нього наукові та комп'ютерні алгоритми (Чернов, 2012).

Слід відрізняти графологію від почеркознавства, точного наукового напрямку, котрий застосовується в криміналістичних експертизах. Головне завдання почеркознавства - встановлення авторства рукопису, можливостей його приховування, виконання під впливом надзвичайних факторів. Визначення властивостей особистості обмежене аспектами віку, статі, перебування в екстремальних психологічних станах. Практикою судовопсихологічних експертиз переконливо доведено, що характерні зміни почерку є інформативним маркером стресу, гострих емоційних станів людини (Линевич, 1998). Треба визнати, що на початку XX ст. кримінальне почеркознавство розвивалося спільно 3 графологією та «запозичило» у останньої опис загальних ознак почерку. Але сьогодні провідні експерти визнають спекулятивний характер графологічних висновків і не рекомендують застосовувати їх при встановленні фактів, що мають доказове та орієнтувальне значення (Орлова, 2007). Положення графології про пряме відображення в 
почерку усього розмаїття властивостей особистості, ïi вольових якостей, здібностей, потягів (аж до кримінальної спрямованості, благонадійності або політичної орієнтації виконавця) визнане утопічним та морально сумнівним (Бобовкин \& Ручкин, 2017). Водночас, інші спеціалісти відзначають, що в цих роботах «можна побачити безліч думок методичного характеру, які заслуговують на увагу» (Ковалев, 2016). Посібники з графології друкує АПН України (Висковатова \& Низовцев, 2008). На сайті Українського центру судових експертиз пропонуються послуги саме 3 формулюванням «графологічна експертиза» (УЦСЭ, 2019).

Підсумовуючи постановку проблеми, відмітимо основні критичні зауваження академічних психологів стосовно графологічного аналізу:

- безпідставність суджень про психологічне значення тих чи інших особливостей почерку та конфігурації літер (достовірність підтримується переважно переконливістю аргументів автора, кейсами-спостереженнями i зверненнями до колективного досвіду графологів);

- відсутність єдиного термінологічного апарату та єдності інтерпретацій;

- формулювання висновків не стільки на основі характеристик письма, скільки на основі іншої доступної інформації про людину (зміст наративних творів, проекція образу відомих особистостей на почерк і т.д.);

- відсутність клінічних та експериментальних підтверджень того, що існує зв'язок між конкретними рисами почерку та рисами особистості, запропонованими графологами; сумніви у принциповій можливості діагностикиіндивідуальнихрис на основі обмеженого аспекту поведінки;

- відсутність поступального розвитку постулатів, ідей та методів всередині самого учіння, що свідчить про його ненауковий характер.

Самі графологи стверджують, що їхня праця - швидше мистецтво, ніж наука: «Результат інтерпретації почерку багато в чому залежить від особистості інтерпретатора-графолога i дуже багато в чому будується на емпатії, відчутті виконавця через його рукописний текст. Почерк чинить на інтерпретатора сугестивну дію, на яку той відгукується» (Кравченко, 2016). Зрозуміло, що 
подібні твердження викликають сумніви не тільки у науковців, a й загалом людей 3 критичним мисленням. Яскрава критика тривіальної графології наведена в проекті Є. Вострікова (Востриков, 2010) «Ніби наука». Автор підкреслює, що сучасна графологія ігнорує здобутки суміжних дисциплін: фізіології, нейропсихології, педагогіки, психології. Відсутність наукового пояснення механізмів індивідуалізації почерку не дозволяє робити скількинебудь об'єктивну оцінку особистісних рис. Таким чином, при комерційному використанні графологія найчастіше представляється шарлатанством або навмисним шахрайством, методом маніпуляції.

Таким чином, ряд емпіричних досліджень останніх десятиріч переконливо демонструє помилковість психологічних висновків, зроблених на основі виконання рукописів. Подібні експерименти, проведені 3 метою підтримки графологічних принципів, не дають однозначно позитивних результатів. Досить часто подібні публікації викликають нарікання 3 методологічної точки зору (використані діагностичні інструменти, об’єм та якість вибірок, методи статистичного підтвердження). Так, у роботі В. Thiry (2009) графологічні змінні порівнюються із змінними тесту Роршаха, а емпіричні висновки О.В. Осєкової (Осекова, 2003) базуються на дослідженні всього 40 осіб - представників чотирьох класичних типів темпераменту.

Водночас, навіть найзапекліші критики погоджуються 3 тим фактом, що результати графологічного аналізу схвально сприймаються замовниками та непідготовленими читачами. Це можна пояснити артефактом сприймання - графологічні профілі зазвичай містять широкий набір різноманітних ознак, частина 3 яких оцінюються як хибні та невідповідні, частина - як нейтральні, а частина співпадає 3 думкою людини про себе. Люди переоцінюють саме збіг з самооцінкою, тому в цілому профілі сприймаються як достовірні. Через «помилку персональної валідації» не можна довіряти даним особистого підтвердження графологічних аналізів (Forer, 1949).

\section{Методики та процедура емпіричного дослідження}

У якості об'єкта емпіричної перевірки ми використали ессе «Як створити кращу копію себе». Предмет вивчення - нахил 
літер - характеристика почерку, яка визначалася за допомогою простих вимірювань. Кут нахилу кількісно вимірювався в інтервальній шкалі, що полегшувало використання математичних процедур. (Попередньо зауважимо, що ця ознака досить глобальна та незмінна для того, щоб трактувати їі як виразний маркер певної психофізіологічної та типологічної організації особистості). Окрім цього, щоб проаналізувати лінгвістичну складову письма, студенти також заповнили анкету на визначення особистості за п’ятифакторним питальником особистості «Велика п’ятірка» (John, Donahue, \& Kentle, 1991). Кожне ессе також було оцінене за 5-бальною шкалою для кожної риси особистості відповідно до ієрархічної моделі особистості (нейротизм (NEU), екстраверсія (EXT), відкритість досвіду (OPN), схильність до згоди (AGR) та сумлінність $(\mathrm{CON}))$. Крім балів, текстова база даних містила бінарні значення для кожної ознаки (висока/низька), які були отримані за допомогою медіани розбиття за балами. Розподіл класів бінарних значень показано в таблиці (табл. 1).

Таблиця 1. Розподіл класів у текстовій базі даних

\begin{tabular}{lccccc}
\hline Ознаки & OPN & CON & EXT & AGR & NEU \\
\hline Низька & $48.46 \%$ & $49.19 \%$ & $48.26 \%$ & $46.92 \%$ & $50.04 \%$ \\
Висока & $51.54 \%$ & $50.81 \%$ & $51.74 \%$ & $53.08 \%$ & $49.96 \%$ \\
\hline
\end{tabular}

\section{Етапи дослідження}

Дослідження проходило в кілька етапів:

1. Збір даних про поширеність та варіативність змінної у достатньо представницькій вибірці. Опитуваними стали студенти старших курсів університету, які навчаються за гуманітарними та фізико-математичними спеціальностями (119 осіб віком від 20 до 32 років). Матеріали дослідження залучали продукти повсякденної письмової діяльності, як-от: зошити з конспектами, робочі записи, щоденники, так i ессе «Як створити кращу копію себе». Нахил визначався за кутом вертикальних ліній відносно горизонтальної основи рядків (великі літери Г та П, малі літери р, ф, т, цифра 4 в анкетах). Метод математично-статистичної обробки отриманих даних: кластеризація в програмі SPSS (ієрархічний кластерний 
аналіз з побудовою дендрограми; метод кластеризації Average Linkage (Between Groups), міра відстані між об'єктами - квадрат евклідової відстані); частотний аналіз. На основі проведеної кластеризації сформували дослідницькі групи з яскраво вираженими типами нахилу почерку: лівостороннім (12 осіб), прямим (23 особи) та правостороннім (50 осіб).

2. Вивчення інтерпретації нахилу в керівництвах 3 графологічного аналізу (всього зібрали 9 випадків, ще від п'яти відмовились через явну повторюваність описів). Складання загальної інтерпретації лівостороннього нахилу як психодігностичної риси на основі проведеного змістовно-семантичного аналізу текстів.

3. Для визначення якості вживання лексичного запасу ми використовували два основні підходи: низхідний аналіз (LIWC та MRC) та висхідних аналіз (тематичне моделювання із латентним розміщенням Діріхле (LDA)). Для визначення якості вживання граматичних структур, ми скористалися підходом Бібера до визначення прикметних характеристик письмового тексту (Biber, 1988). Комп'ютерна програма LIWC2007 допомогла нам оцінити ессе за, загалом, 80 параметрами, зокрема: відносна частота слів, знайдених у кожній попередньо визначеній категорії, та структурні особливості, такі як загальна кількість слів та кількість слів на одне речення. Відповідно до MRC підходу, ми застосували 14 показників, якими є: довжина слова, кількості складів або фонем, а також значення частоти використання, зображуваності, конкретності, тощо. Показники MRC були розраховані шляхом усереднення балів за кількість слів у ессе, знайдених у текстовій базі даних (на відміну від усереднення по загальній кількості слів). Ми підготували п'ять класифікаторів згідно методу опорних векторів (SVM) з лінійним ядром, по одному для кожної риси особистості. SVM були обрані завдяки попереднім їх описам, в яких зазначалося, що вони відповідають такому задання краще, ніж інші алгоритми (Mairesse et al., 2007), а лінійні ядра були використані для забезпечення інтерпретаційності моделі. Для реалізації дослідження ми використовували бібліотеку машинного навчання Scikit-learn, яка, в свою чергу, використовує основу Libsvm. Класифікатори були налаштовані без модифікацій (тобто, штрафний параметр $\mathrm{C}=1,0$ ).

4. Формулювання питань для перевірки ефекту персональної валідації у вибірці студентів. Вислови графологів ми майже дослівно 
Verification of Psychodiagnostic Capabilities of Handwritten Texts

відтворили у анкеті, призначеній для визначення схильності погоджуватися 3 такими твердженнями (всього сформулювали 22 питання). Респондентів просили оцінити ступінь своєї згоди 3 запропонованими твердженнями за допомогою 5-бальної шкали: 1 ніколи, 2 - рідко, 3 - іноді, 4 - часто, 5 - завжди.

На етапі обробки підсумували оцінки по кожному питанню в групах 3 різними типами нахилу почерку - рис. 1. Значущість міжгрупової різниці була визначена за допомогою S-критерію тенденцій Джонкіра (Сидоренко, 2004), підрахунки здійснювались в програмі SPSS 16.0.

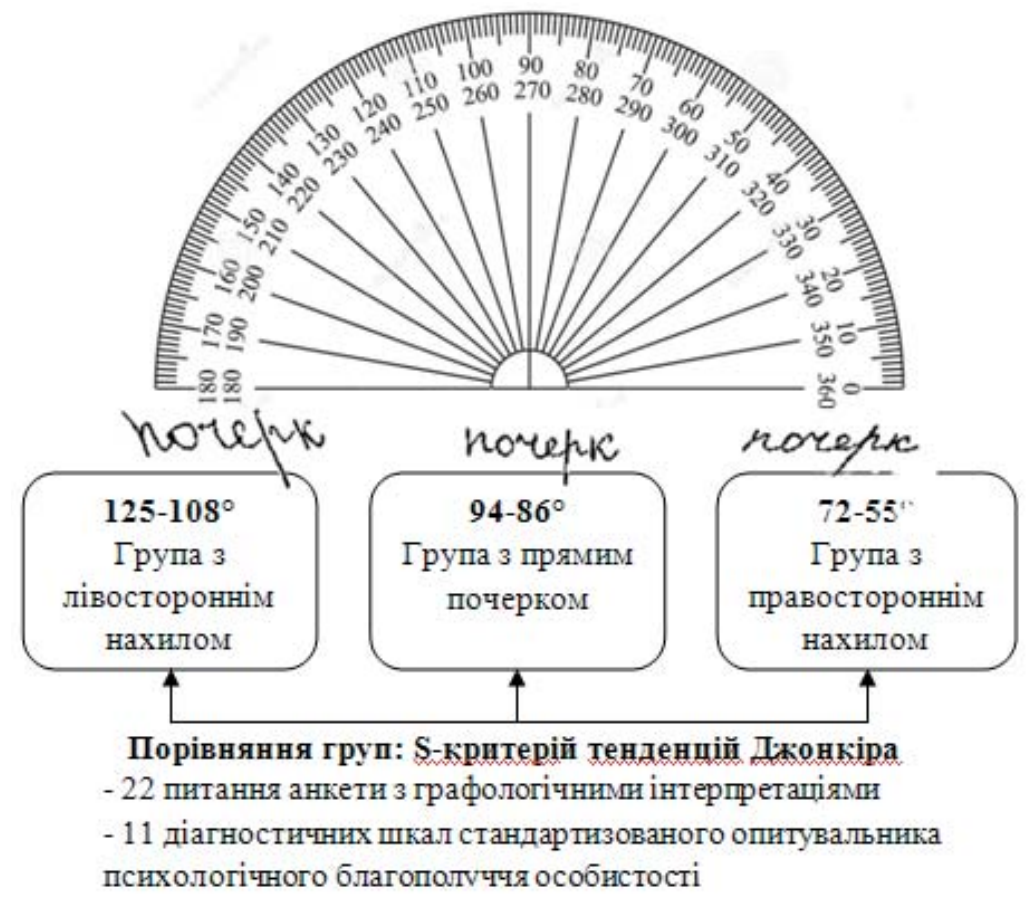

Рис. 1. Дизайн емпіричного дослідження психолінгводіагностичного потенціалу почерку

5. Перевірка валідності графологічної інтерпретації лівостороннього нахилу за допомогою стандартизованих опитувальників 3 визнаною психометричною компетентністю. Була використана Шкала психологічного благополуччя К. Ріфф в адаптації Т.Д. Шевеленкової, П.П. Фесенко (Шевеленкова \& Фесенко, 2005). Результати психологічної діагностики в групах 
представлені у вигляді середнього $\pm \mathrm{SD}$; перевірка статистичної відмінності розподілів проведена, як і в попередньому випадку, за допомогою S-критерію тенденцій Джонкіра.

\section{Результати емпіричного дослідження та дискусії}

\section{1. Особливості нахилу рукописного тексту у вибірці студентів.}

Вимірювався нахил почерку в рукописних матеріалах 119 студентів різних спеціальностей. Процедура кластерного аналізу дозволила впорядкувати отриманий масив даних у відносно однорідні групи, котрі можна розглядати як природно існуючі типи почерку. Кластеризація розділила опитуваних на шість груп різного розміру. В табл. 2 представлені результати всієї вибірки, а також поширеністьтипів середосіб різної статі.

Таблиця 2. Кластери даних, виділені на основі кута нахилу почерку студентів (абсолютні значення та \%)

\begin{tabular}{|c|c|c|c|c|c|c|}
\hline \multicolumn{7}{|c|}{ Кут нахилу літер відносно горизонтальної основи листа } \\
\hline & \multicolumn{2}{|c|}{ Лівосторонній нахил } & \multirow{2}{*}{$\begin{array}{l}\text { Прямий } \\
94-86^{\circ *}\end{array}$} & \multicolumn{3}{|c|}{ Правосторонній нахил } \\
\hline & $125-108^{\circ *}$ & $105-98^{\circ}$ & & $82-75^{\circ}$ & $72-55^{\circ *}$ & $50-34^{\circ}$ \\
\hline $\mathrm{n}=\mathbf{1 1 9}$ & $12(9,8 \%)$ & $7(6,2 \%)$ & $23(19,1 \%)$ & $18(14,9 \%)$ & $50(41,9 \%)$ & $9(8,1 \%)$ \\
\hline Чоловіки $(n=54)$ & $6(10,9 \%)$ & $4(7,2 \%)$ & $11(20,3 \%)$ & $9(16,9 \%)$ & $18(32,8 \%)$ & $6(10,9 \%)$ \\
\hline Жінки $(n=66)$ & $7(10,8 \%)$ & $3(5,1 \%)$ & $12(17,7 \%)$ & $9(14,2 \%)$ & $32(47,1 \%)$ & $3(5,1 \%)$ \\
\hline
\end{tabular}

Прим.: * - категорії, обрані для наступного порівняльного аналізу

Прояви право- або лівостороннього почерку є неоднорідними і містять різні ступені виразності. Найпоширенішим серед студентів $\epsilon$ правостороннє письмо з трьома варіантами нахилу (типовим можна вважати нахил $72-55^{\circ}$, виявлений у $41,9 \%$ вибірки). Виразний лівосторонній почерк виявлений у 9,8\% опитаних, ще $6,2 \%$ пишуть 3 кутом нахилу $105-98^{\circ}$. В третині випадків цей нахил пояснюється ліворукістю.

Поширеність лівостороннього нахилу не залежить від статі, в той час як виразний правосторонній (кут менше 50) властивий переважно чоловікам.

Особливістю вибірки $\epsilon$ активна письмова діяльність, тож отримані дані характерні для дорослих із сформованими 
рухово-письмовими навичками. Наша статистика не відповідає даним графологічних джерел, де найбільш поширеним називають почерк 3 кутом нахилу 45-50 (Зуев-Инсаров, 1992). Щоправда, попередні дані стосовно нахилу, наведені Д.М. Зуєвим-Інсаровим, стосуються ще початку XX ст. Графолог пише, що після першої світової війни збільшилася частка людей, які пишуть вертикальним почерком (від 10\% до 35\%). Ю.Г. Чернов (Чернов, 2012) відзначає, що раніше в школах домінувала тенденція до виразно правого нахилу, а пізніше учнів навчали більш прямому почерку. Це свідчить про існування певних соціально-культурних факторів, що впливають на формування почерку як складової загальної мовної культури особистості.

Результати визначення якості вживання лексичного запасу i вживання граматичних структур представлені в табл. 3.

Таблиця 3. Результати визначення якості вживання лексичного запасу i вживання граматичних структур представлені, для кожного класу 3 довірчим діапазоном 95\%

\begin{tabular}{|c|c|c|c|c|c|c|c|}
\hline & & $\begin{array}{c}\text { Вихідні } \\
\text { дані }\end{array}$ & $\begin{array}{c}\text { Словни- } \\
\text { ковий } \\
\text { запас, }\end{array}$ & $\begin{array}{l}\text { Словни- } \\
\text { ковий } \\
\text { запас, }\end{array}$ & Граматика & Комбін & ування \\
\hline & & $\begin{array}{c}\text { (A) } \\
\text { Більщість }\end{array}$ & $\begin{array}{c}\text { (B) } \\
L I W C+M R C\end{array}$ & $\begin{array}{c}(C) \\
L I W C\end{array}$ & $\begin{array}{c}\text { (D) } \\
\text { Biber }\end{array}$ & $\begin{array}{c}(E) \\
\text { Biber }+ \text { LIWC }\end{array}$ & $\begin{array}{c}(F) \\
\text { Biber }+M R C\end{array}$ \\
\hline OPN & $\begin{array}{c}\Pi \\
\mathrm{T} \\
\mathrm{BM}\end{array}$ & $\begin{array}{c}.515 \\
.515 \\
1 .\end{array}$ & $\begin{array}{l}.617 \pm .006 \\
.634 \pm .006 \\
.611 \pm .010\end{array}$ & $\begin{array}{l}.606 \pm .006 \\
.617 \pm .006 \\
.605 \pm .01\end{array}$ & $\begin{array}{l}.576 \pm .007 \\
.586 \pm .007 \\
.607 \pm .010\end{array}$ & $\begin{array}{l}.602 \pm .006 \\
.619 \pm .006 \\
.614 \pm .009\end{array}$ & $\begin{array}{c}.602 \pm .006 \\
.615 \pm .006 . \\
612 \pm .010\end{array}$ \\
\hline CON & $\begin{array}{c}\Pi \\
\mathrm{T} \\
\mathrm{BM}\end{array}$ & $\begin{array}{c}.508 \\
.508 \\
1 .\end{array}$ & $\begin{array}{l}547 \pm .006 \\
.550 \pm .005 \\
.607 \pm .009\end{array}$ & $\begin{array}{l}.551 \pm .006 \\
.553 \pm .006 \\
.611 \pm .010\end{array}$ & $\begin{array}{l}.551 \pm .006 \\
.554 \pm .006 \\
.599 \pm .010\end{array}$ & $\begin{array}{l}.546 \pm .006 \\
.550 \pm .006 \\
.588 \pm .010\end{array}$ & $\begin{array}{l}.548 \pm .007 \\
.551 \pm .006 \\
.598 \pm .009\end{array}$ \\
\hline EXT & $\begin{array}{c}\Pi \\
\mathrm{T} \\
\mathrm{BM}\end{array}$ & $\begin{array}{c}.517 \\
.517 \\
1 .\end{array}$ & $\begin{array}{l}.562 \pm .007 \\
.570 \pm .006 \\
.624 \pm .010\end{array}$ & $\begin{array}{l}.545 \pm .006 \\
.554 \pm .005 \\
.624 \pm .010\end{array}$ & $\begin{array}{l}.546 \pm .007 \\
.553 \pm .006 \\
.635 \pm .010\end{array}$ & $\begin{array}{l}.553 \pm .007 \\
.562 \pm .006 \\
.614 \pm .010\end{array}$ & $\begin{array}{l}.557 \pm .007 \\
.563 \pm .006 \\
.644 \pm .010\end{array}$ \\
\hline AGR & $\begin{array}{c}\Pi \\
\mathrm{T} \\
\mathrm{BM}\end{array}$ & $\begin{array}{c}.531 \\
.531 \\
1 .\end{array}$ & $\begin{array}{l}.545 \pm .007 \\
.561 \pm .006 \\
.651 \pm .011\end{array}$ & $\begin{array}{l}.552 \pm .007 \\
.567 \pm .005 \\
.664 \pm .010\end{array}$ & $\begin{array}{l}.549 \pm .006 \\
.562 \pm .005 \\
.678 \pm .010\end{array}$ & $\begin{array}{l}.552 \pm .006 \\
.570 \pm .005 \\
.636 \pm .010\end{array}$ & $\begin{array}{l}.553 \pm .007 \\
.570 \pm .006 \\
.649 \pm .010\end{array}$ \\
\hline NEU & $\begin{array}{c}\Pi \\
\mathrm{T} \\
\mathrm{BM}\end{array}$ & $\begin{array}{c}.500 \\
0 . \\
0 .\end{array}$ & $\begin{array}{l}.565 \pm .007 \\
.563 \pm .007 \\
.577 \pm .012\end{array}$ & $\begin{array}{l}.571 \pm .006 \\
.571 \pm .007 \\
.571 \pm .011\end{array}$ & $\begin{array}{l}.545 \pm .006 \\
.545 \pm .006 \\
.535 \pm .010\end{array}$ & $\begin{array}{l}.552 \pm .006 \\
.552 \pm .006 \\
.551 \pm .011\end{array}$ & $\begin{array}{l}.545 \pm .007 \\
.544 \pm .006 \\
.550 \pm .011\end{array}$ \\
\hline
\end{tabular}

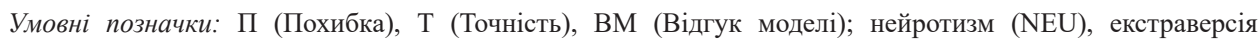
(ЕXT), відкритість досвіду (OPN), схильність до згоди (AGR) та сумлінність (CON)). 
Наше дослідження цього аспекту виявило значну складність ідентифікації рис особистості зі змістових показників тексту. Погоджуємося 3 В. Мішель і Я. Шода (Mischel \& Shoda, 1995), які стверджували, що індивідуальні відмінності в соціальній поведінці насправді змінюються в різних ситуаціях (ситуативність) i не $є$ повністю стійкими. Таким чином, якщо продукування тексту особистістю та текстовий аналіз попадають у різні соціальні ситуації, завдання, які використовуються з метою отримання певного результату як золотого стандарту, не зможуть продемонструвати прийнятні показники.

У процесі дослідження ми виявили важливу особливість близько третини вибірки мають два «робочі» типи почерку, які відрізняються нахилом. Тому отримані дані не є остаточними.

2. Інтерпретації лівостороннього письма в графологічних джсерелах: змістовно-семантичний аналіз.

Правосторонній нахил - типова ознака мовної культури та норм письма. Графологи відзначають цей факт: Д.М. Зуєв-Інсаров (Зуев-Инсаров, 1992) описує цей нахил як найбільш зручний (у напрямку руху літер, оскільки ми пишемо зліва направо); I. Гольдберг (Гольдберг, 2012) називає правий нахил природним та найменш енерговитратним; В. Тараненко пояснює, що таким чином «рука ніби біжить в майбутне, встигаючи за думкою» (Тараненко, 2001). Очевидно, що будь-які психологічні інтерпретації цієї ознаки будуть невиправдано широким узагальненням, хоча це не заважає графологам приписувати правосторонньому нахилу діагностичну значущість.

В якості діагностично-інформативної змінної нас цікавило відхилення від норми, звичайного правостороннього нахилу. Д.М. Зуєв-Інсаров (до речі, володар прямого підпису) пояснює, що в школі всіх учать писати вправо, однак деякі не можуть підкоритися загальним правилом і креслять вертикальні літери: вони несвідомо слідують внутрішньому інстинкту, сильнішому за прищеплені звички (Зуев-Инсаров, 1992). Розглянемо, яким чином ці випадки інтерпретуються в керівництвах з графології.

Цей етап дослідження був присвячений роботі 3 текстами першоджерел. Ми відшукали пояснення та інтерпретації лівостороннього нахилу в публікаціях 3 графології, порівняли 
їх, виділили основні змістовні категорії. Результати пошуку представлені в табл. 4.

Таблиця 4. Інтерпретації лівостороннього нахилу літер у першоджерелах 3 графологічного аналізу

$\begin{array}{cc}\begin{array}{c}\text { Автор та рік } \\ \text { видання }\end{array} & \text { Текст, що стосусться } \\ \text { лівостороннього нахилу у письмі }\end{array}$

І. Моргенштерн
(Моргенштерн, 1903)

В. Маяцький Похилий навпаки. Неприродність, манірність, хитрість, (Маяцкий, 1907) деспотизм, скритність, недовіра, страх власного почуття.

Д. Зуєв-Інсаров Перевернений вліво $\left(125^{\circ}\right)$ почерк, проти напрямку руху, (Зуев-Инсаров, 1929) виникає найчастіше в результаті невідповідності особистих природних схильностей $i$ потягів люоини 3 зовнішніми умовами виховання $\boldsymbol{i}$ життя. Перевернутий почерк вказує на норовливість, упертість, вимогливість, недовірливість, іноді нещирість і скритність. ... свідчить про бажання зайняти особливе місце, бажанні йти всупереч загальній думці.

(Щеголев, 2005)

В. Тараненко

(Тараненко, 2005)
І. Щеголев

... у такої людини помітний контроль розуму над серцем.

У разі ще більшою перевернутого почерку люди дуже скупо проявляють свої почуття, у них явно проступає тенденція до скритності, холодності і великий стриманості

Проти градіснта. Лівий нахил у правшів - очевидний нонсенс... Чого це раптом рука пишучого виводить рядки або окремі слова, фрагменти, немов задкуючи задом наперед? Або - не важливо куди, аби всупереч? Мабуть, в кожній людині закладено спокуса вчинити не так, як всі, або зробити не так, як завжди. ... протистояти чому-небудь для нього найперше задоволення, а не якийсь прагматичний розрахунок ... мотивації робити або чинити всупереч. ... зворотний нахил букв висловлює внутрішню, найчастіше підсвідому опозицію пишучого не тільки по відношенню до зовнішнього оточення, але перш за все - по відношенню до самого себе.

«Шкідливість» - не що інше, як спроектоване зовні невдоволення самим собою. «Контрреволюція» пишучої руки є явний прояв особистісної самоконфліктності, внутрішньої неузгодженості... Звичайно, заперечуючи будь-який світопорядок, а разом 3 ним і якусь частину самого себе, можна досягти багато чого, але ніколи не досягти рятівного душевного комфорту. ... вперті й наполегливі ... Крім того, «які йдуть проти» не потребують сигналів схвальної підтримки не тільки зверху, але і знизу.

Т.П. Вісковатова \& Написання букв 3 нахилом в ліву сторону вказує на наявність Н.В. Низовцев (Висковатова \& Низовцев, 2008) в структурі особистості прагнення дотримуватися тільки власної думки всупереч загальноприйнятій 
I. Гольдберг

(Гольдберг, 2012)
... нахил «показує» одну 3 основних тенденцій в устрої особистості людини, іiї спрямованість, іiї природу і яким чином вона її проявляє ... він пов'язаний $з$ динамічними параметрами почерку, з рухом ... Якщо правий нахил - «спуск», то прямий можна порівняти 3 прямою поверхнею... Аналогічно аналіз відбувається і з лівим нахилом, ми можемо умовно уявити собі його в якості «опору», «сходження в вгору».

«Сходження в вгору»- нераціонально, умовно «сізіфова праця» (якщо потрібно дійти, гору можна було просто обійти), це зосередження саме на «горі», на власноруч спорудженій собі перешкоді, бар'срі, щцо відокремлює себе - від людей, соціуму, цілей, прямої взаємодії з навколишнім середовищем.

Так, це закриття своєї природи і стримування себе, свойх почутmів, але тут немає нічого «раціонального», це не розум, a захист людини, якій важкко. Лівий нахил = опозиція, i позиціонування себе саме так, «проти» оточенню.

С. Сибірська

(Сибирская, URL)
Лівий нахил - представляє внутрішній світ, минуле. Його самоусвідомлення тяжіє до усамітнення, відстороненості. Він ніби прагне повернутися до матері, бути дитиною під захистом матері. Лівий нахил є показником наявності бар'єру міжс собою $\boldsymbol{i}$ зовнішнім світом. Помірно лівий (1-10 град. вліво від вертикалі) зображує відстороненої, усамітненої людини,... Можлива регресія емоцій і подій. Ці люди відштовхують від себе зовнішнє середовище. Живуть у своєму внутрішньому світі, не стикаючись 3 зовнішнім і мають труднощі в адаптації до певних ситуацій. Вони рідко висловлюють свої емоції відкрито, вважають, щңо це недоречно. ... показово для пригніченого стану, в результаті якого сформувалася відстороненість від дійсності, побоювання майбутнього i можливо відторгнення батьків. Причиною цього може бути пригнічене, травмуюче дитинство....

Вони контролюють свої прояви емоцій, зовні здаються холодними, будучи насправді всередині досить емоційні.

Світові школи графології (за переказом сайту grafol.ru)

\begin{tabular}{ll}
\hline Графологічна школа & Перевернений лист (лівонахилений). Ця ознака листа \\
Парижу & видає оборону людини, постійні побоювання i бажання \\
& захиститися від явних, але часто від уявних небезпек.
\end{tabular}

Американська графологічна школа
Емоційно пригнічена людина, зациклена на своїх переживаннях. Вона проявляє свої почуття тільки в моменти великого гніву, великої пристрасті або величезної напруги. У решту часу, вона зовні холодна $\boldsymbol{i}$ стримана. Приймає рішення на основі холодного розрахунку, вона рідко буває імпульсивною і не має потреби висловлювати свої почуття відкрито. Така людина вважає, що вираз емоцій - марна трата сил. Для оточуючих людей вона загадка, важко передбачити, які почуття вона відчуває. Така людина полюбляє бути одна і вважсає за краще працювати наодинці. ... що більшість людей з таким нахилом, 
Verification of Psychodiagnostic Capabilities of Handwritten Texts

перенесли в дитинстві глибоку фізичну чи психічну травму.

I тепер вони побоюються довіряти людям. Лівий нахил свідчить про те, щцо будучи дитиною, людина не відчувала себе захищеною.

Прим.: виділені жирним курсивом одиниці тексту, використані в анкеті для визначення ефектів персональної валідації

3 наведених уривків наочно простежується еволюція уявлень про інтерпретації лівостороннього нахилу в працях графологів. Фактично ці описи представляють собою філософствування навколо раніше опублікованих текстів - 3 додаванням деталей та власних асоціацій автора. Більшість сучасних російськомовних інтерпретацій, присвячених лівосторонньому нахилу, по суті, закладені більше 100 років тому І.Ф. Моргенштерном (Моргенштерн, 1903) та Д.М. Зуєвим-Інсаровим (Зуев-Инсаров, 1992). Це ознака відсутності розвитку теоретичних знань, нездатності до накопичення та осмислення емпіричних спостережень (що знову повертає нас до думки про ненауковість графологічного методу).

Змістовно-семантичний та термінологічний аналіз тверджень, зібраних в таблиці 2, показує що тлумачення однієї ізольованої риси почерку містить найширший спектр інтерпретацій, які стосуються багатьох сфер психічного життя - від емоцій до досвіду дитячих травм. Разом 3 тим, можна виділити декілька загальних тем: мотивація «діяти всупереч», стриманість емоційних проявів, інтровертованість, невдоволеність собою і зовнішніми обставинами.

Загалом зміст інтерпретацій фокусується навколо лексикосемантичної групи «поперечність», що $є$ прямою асоціацією до характеристики письма (рис. 2).

Bсе вищесказане призводить нас до висновку, що в основі наданих інтерпретацій не реальні спостереження за проявами психічних властивостей носіїв певних різновидів почерку, а власні асоціації авторів. При цьому характеристики почерку як продукту автоматизованої дії безпосередньо переносяться на характеристики особистості. 3 цим висновком погоджується критика графології. Є. Востриков (2010) відзначає антропоморфізм аналізу почерку наділення людськими якостями неживих предметів. П. Грейслер (Greasley, 2000) характеризує цей метод як «творче використання аналогії, символізму та метафори». Р. Кінг і Д. Кохлер (King \& Koehler, 2000) пояснюють, що семантичний зв'язок між словами, 
які використовують для опису почерку та особистісних рис, сприяє тому, що люди погоджуються з висновками графологів.

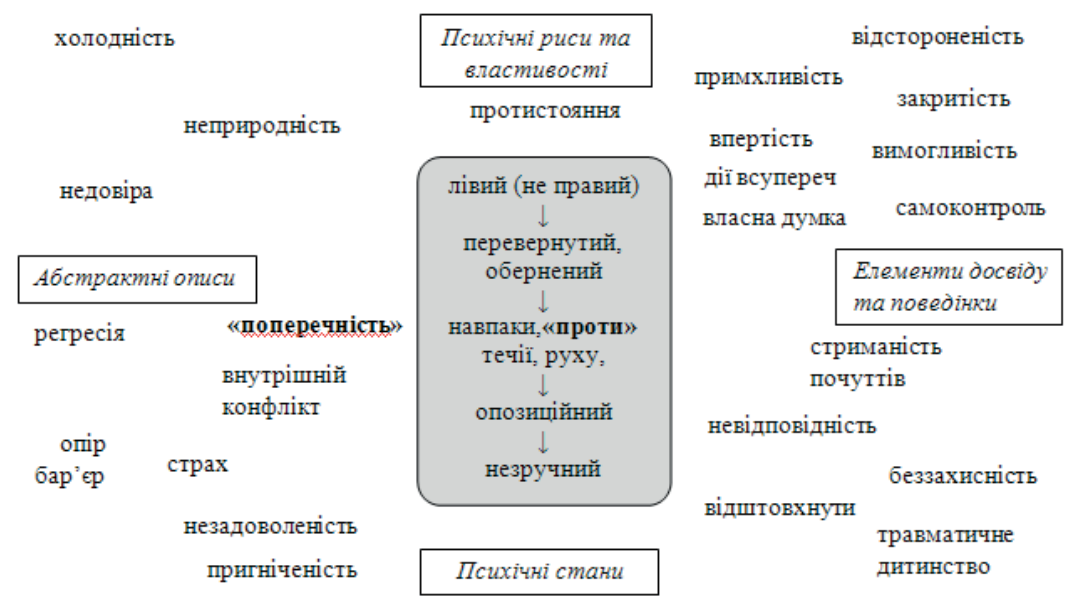

Рис. 2. Семантичне поле інтерпретаиій, що виражають поняття «поперечність» як відображення характеристики письма «супротив»

\section{3. Перевірка персональної валідації графологічних}

\section{інтерпретацій.}

Якщо висновки графологів носять непідтверджений та умоглядний характер, чому більшість осіб, які пробують цю послугу, відмічають високий ступінь збігу отриманих профілів 3 дійсністю? Критики називають в якості основної причини помилку сприйняття, ефект персональної валидації.

Вислови графологів (підкреслені у табл. 2) ми відтворили у анкеті, призначеній для визначення схильності погоджуватися 3 твердженнями. Ми запропонували анкету всім опитуваним, отримані оцінки порівняли в групах 3 різними типами нахилу почерку (табл. 5).

Стосовно ряду тверджень анкети усі без виключення опитувані висловилися позитивно (поставили оцінки від 3 до 5, що відповідає ступеням виразності «іноді», «часто» або «завжди»). Серед характеристик, 3 якими погоджуються і приписують собі: «Я буваю впертим(ою)», «Хочу чинити не так, як всі або робити не так, як завжди», «Моє життя можна порівняти із сходженням на гору», «Незадоволений(а) собою», «Майбутнє лякає мене», «Переважно контролюю власні емоції», «Навколишнім важко 
здогадатися про мої справжні думки та почуття», «Я готовий оборонятися, навіть якщо явних неприємності немає», «Стараюсь дотримуватись власної думки і не слідувати загальній течії». Отже, ці формулювання жодним чином не диференціюють опитаних i не мають діагностичної цінності.

Таблиця 5. Середні оцінки в групах щодо тверджень - графологічних інтерпретаційлівостороннього нахилу (оцінки за 5-бальною шкалою)

\begin{tabular}{|c|c|c|c|}
\hline \multirow[b]{2}{*}{ Зміст твердження } & \multicolumn{3}{|c|}{ Ідентифікаційні ознаки груп } \\
\hline & $\begin{array}{l}\text { Лівий } \\
\text { нахил }\end{array}$ & $\begin{array}{c}\text { Прямий } \\
\text { почерк }\end{array}$ & $\begin{array}{c}\text { Правий } \\
\text { нахил }\end{array}$ \\
\hline Я буваю впертим(ою) & 4,1 & 4,0 & 3,8 \\
\hline Я вимогливий(а) до інших & 3,7 & 2,8 & $4,4 *$ \\
\hline Власні почуття лякають мене & 2,5 & 3,2 & 2,8 \\
\hline $\begin{array}{l}\text { Зовнішні умови життя не відповідають моїм природним } \\
\text { схильностям та бажанням }\end{array}$ & 1,8 & 3,5 & 3,2 \\
\hline Я йду всупереч загальній думці & 1,6 & 3,1 & 3,1 \\
\hline Гадаю, краще не довіряти людям & 3,2 & 2,4 & $3,9 *$ \\
\hline Я людина, у якої розум головніше за серце & 3,9 & 2,6 & 3,7 \\
\hline Хочу чинити не так, як всі або робити не так, як завжди & 3,9 & 4,1 & $4,4^{*}$ \\
\hline Незадоволений(а) собою & 3,6 & 4,2 & 4,3 \\
\hline Не відчуваю душевного комфорту & 2,5 & 3,9 & 3,1 \\
\hline Моє життя можна порівняти із «сходженням на гору» & 3,9 & 4,4 & 3,6 \\
\hline $\begin{array}{l}\text { Я самостійно будую перешкоди між собою та світом, } \\
\text { іншими людьми, власними цілями }\end{array}$ & 1,8 & 3,9 & $3,9^{*}$ \\
\hline $\begin{array}{l}\text { Моя стриманість - це захист людини, якій насправді } \\
\text { важко }\end{array}$ & 3,7 & 3,5 & 3,1 \\
\hline Мені краще бути та працювати наодинці & 2,5 & 3,8 & 2,7 \\
\hline $\begin{array}{l}\text { Вважаю, що відкрито проявляти емоції - недоречно і } \\
\text { небезпечно }\end{array}$ & 4,9 & 3,3 & 3,5 \\
\hline Майбутнє лякає мене & 4,0 & 4,1 & 3,9 \\
\hline $\begin{array}{l}\text { Моє дитинство було нелегким, я не відчував себе } \\
\text { захищеним. }\end{array}$ & 2,3 & 3,7 & $3,8^{*}$ \\
\hline Переважно контролюю власні емоції. & 4,3 & 4,2 & 4,2 \\
\hline $\begin{array}{l}\text { Навколишнім важко здогадатися про мої справжні думки } \\
\text { та почуття }\end{array}$ & 4,4 & 3,4 & 3,3 \\
\hline $\begin{array}{l}\text { Я готовий оборонятися, навіть якщо явних неприємності } \\
\text { немає }\end{array}$ & 4,5 & 3,6 & 4,6 \\
\hline Вважаю, що виражати свої емоції - пуста витрата сил & 2,2 & 3,8 & 3,2 \\
\hline $\begin{array}{l}\text { Стараюсь дотримуватись власної думки і не слідувати } \\
\text { «загальній течії» }\end{array}$ & 4,5 & 4,6 & 4,1 \\
\hline
\end{tabular}

Прим.: * - статистично підтверджена різницяя розподілу даних в групах (S-критерій тендениій Джонкіра на рівні значущості 0,05). 
Стосовно п’яти пунктів анкети отримані показники, що підтверджують статистичну різницю між групами з різним нахилом почерку (на рівні достовірності $\mathrm{p} \leq 0,05$ ). Але звертаємо увагу, що в усіх випадках ознаки, приписані графологами володарям лівостороннього почерку, мають більшу виразність у людей, почерк яких є прямим або правостороннім.

У підсумку жодна із представлених в анкеті 22 графологічних інтерпретацій лівого нахилу не виявилася дійсно виразнішою у групі $з$ лівостороннім почерком. Це $є$ однозначним доказом помилковості графологічного підходу. Ми показали, що графологічні описи містять широкий перелік загальновизнаних психологічних характеристик. Це сприяє тому, що люди в цілому погоджуються 3 ними як достовірними.

4. Пошук відмінностей в групах з різним нахилом почерку за допомогою валідного психодіагностичного інструментарію.

Якщо графологічний аналіз містить недостовірні інтерпретаціїфантазії, можливо існують інші, більш валідні пояснення відмінностей у нахилі? Або ж почерк взагалі не є діагностичним маркером, за яким можна вивчати психічні явища? Для відповіді на ці питання ми порівняли в групах результати стандартизованої діагностичної методики, спрямованої на вимірювання психологічного благополуччя особистості (табл. 6).

Таблиця 6. Діагностичні параметри Шкали психологічного благополуччя Ріфф в групах з різним нахилом почерку (середнє $\pm \mathrm{SD}$ )

\begin{tabular}{|c|c|c|c|}
\hline \multirow[b]{2}{*}{ Діагностичні параметри } & \multicolumn{3}{|c|}{ Ідентифікаційні характеристики груп } \\
\hline & $\begin{array}{c}\text { Лівосторонній } \\
\text { нахил }\end{array}$ & $\begin{array}{l}\text { Прямий } \\
\text { почерк }\end{array}$ & $\begin{array}{c}\text { Правосторонній } \\
\text { нахил }\end{array}$ \\
\hline \multicolumn{4}{|l|}{ Основні шкали } \\
\hline Позитивні відносини з оточуючими & $60,1 \pm 7,3$ & $62,1 \pm 7,0$ & $61,7 \pm 6,9$ \\
\hline Автономія & $58,3 \pm 7,7$ & $60,7 \pm 6,9$ & $57,5 \pm 7,5$ \\
\hline Управління середовищем & $55,8 \pm 8,1$ & $58,4 \pm 7,8$ & $62,3 \pm 8,7 *$ \\
\hline Особистісний ріст & $64,9 \pm 5,4$ & $65,1 \pm 6,1$ & $64,9 \pm 7,2$ \\
\hline Цілі в житті & $64,0 \pm 7,1$ & $61,3 \pm 8,2$ & $62,8 \pm 6,6$ \\
\hline Самоприйняття & $60,9 \pm 6,6$ & $65,1 \pm 6,3$ & $63,4 \pm 5,8$ \\
\hline Індекс психологічного благополуччя & $366,7 \pm 21,5$ & $370,7 \pm 20,7$ & $368,3 \pm 21,8$ \\
\hline \multicolumn{4}{|l|}{ Додаткові шкали } \\
\hline Шкала «Баланс афекту» & $83,6 \pm 10,1$ & $91,1 \pm 9,5$ & $90,7 \pm 10,3 *$ \\
\hline Шкала «Осмислення життя» & $97,8 \pm 9,2$ & $99,3 \pm 9,3$ & $98,5 \pm 9,0$ \\
\hline Шкала «Людина як відкрита система» & $65,1 \pm 7,2$ & $65,2 \pm 6,9$ & $65,0 \pm 7,8$ \\
\hline Шкала «Автономія» & $42,4 \pm 5,5$ & $39,6 \pm 6,1$ & $40,7 \pm 5,8$ \\
\hline
\end{tabular}


Verification of Psychodiagnostic Capabilities of Handwritten Texts

Виявлені два випадки статистично значущої різниці між групами 3 різним нахилом почерку. Показники шкали «Управління середовищем» мають більшу виразність в групі в правостороннім нахилом $(\mathrm{p} \leq 0,05)$. Високі та нормативні значення за цією шкалою свідчатьпро почуття впевненості, компетентність в управлінні повсякденними справами, здатність ефективно використовувати життєві обставини, вибирати та створювати умови, що задовольняють особистісним потребам і цінностям. За додатковою шкалою «Баланс афекту» отримані достовірно нижчі показники в групі 3 лівостороннім почерком $(\mathrm{p} \leq 0,05)$. Шкала описує загальну емоційну оцінку себе і власного життя (Шевеленкова \& Фесенко, 2005). Низькі бали свідчать про переважання позитивної самооцінки, в тому числі власної здатності підтримувати контакти з іншими людьми; прийняття власних переваг та недоліків, впевненість у собі та загальну задоволеність власним життям.

Отримані результати частково підтримують, а частково суперечать наведеним вище графологічним описам. Вони дали нам змогу стверджувати, що почерк є важливою інформативною психологічною ознакою, він певною мірою концентрує в собі психологічні й індивідуальні особистісні властивості виконавця рукописного тексту.

\section{Висновки}

Психографологія в тому вигляді, в якому представлена на сучасному етапі, не $є$ інструментом професійної психологічної діагностики. Наше дослідження підтвердило, що графологічні аналізи не містять діагностично цінної інформації; вони сформульовані у невизначених термінах, які можна інтерпретувати максимально широко та віднести до більшості людей. Проте почерк як сформований динамічний стереотип та має потенціал в якості вимірювальної методики широкого спрямування. Використання рукописних текстів для вивчення особистості потребує акуратності, виваженості й можливе тільки в комплексі 3 іншими характеристиками тексту. Потрібно теоретично пояснити механізм індивідуалізації почерку, провести масштабну пошуководослідницьку роботу із систематизації ознак, співвіднесення їх 
3 валідним психодіагностичним інструментарієм. Дана стаття містить зразок методології подібного дослідження, але вона не дає вичерпної інформації про діагностичні можливості рукописного тексту. Цією роботою нами доведено, що аналіз почерку може виступати предметом наукового дослідження, до якого застосовні визнані в сьогочасній психолінгвістиці методологічні процедури.

\section{Література}

Бобовкин, М.В., \& Ручкин, В.А. (2017). Судебно-почерковедческая диагностика и графология: актуальные вопросы теории и практики. Правовая парадигма, 16(3), 136-140. https://doi.org/10.15688/lc.jvolsu.2017.3.23

Висковатова, Т.П., \& Низовцев, Н.В. (2008). Определение характерологических особенностей подследственного по почерку. Одесса: ПНЦ АПН Украины.

Волкова, А.Г. (2014). Диагностика душевного страдания: психологолингвистический анализ письменного текста в судебной экспертизе. Psycholinguistics. Психолінгвістика. Психолингвистика, 16, 203-211.

Востриков, Е. (2010). Тривиальная графология. URL: https://psyfactor.org/lib/ grafologia.htm

Гольдберг, И. (2012). Графология: «По наклонной?» или секрет наклона почерка. URL: https://psyfactor.org/lib/graphology8.htm

Графология - Азбука личности (n.d.). Персональный сайт С. Сибирской. URL: http://grafol.ru

Зуев-Инсаров, Д.М. (1992). Почерк и личность. Киев: Перлитпродакшн, ЛТД.

Ковалев, П.А. (2016). Роль графологической теории в судебном почерковедении. Исторические, философские, политические и юридические науки, культурология и искусствоведение. Вопросы теории и практики, 4(66), 71-75.

Кравченко, В.И. (2016). Человек в аспектах графологии: философскоантропологический анализ. Вестник ЛГУ им. А.С. Пушкина, 3, 126-132.

Леонтьев, А.А. (1999). Основы психолингвистики. Москва: Смысл.

Линевич, В.Л. (1998). Психофизиологические предикторы дискоординации почерка при стрессе. Дисс. канд. психол. наук. Уфим. фил. фак. психологии МГУ им. М.В. Ломоносова, Уфим. юрид. ин-т МВД России. Уфа.

Максименко, С., \& Орап, М. (2015). Психолінгвістичні предиктори здоров'я. Psycholinguistics. Психолінгвістика. Психолингвистика, 18(1), 252-269. https://doi.org/10.31470/2309-1797-2018-24-1-252-268

Маяцкий, В. (1990). Графология. (Репринтное воспроизведение издания 1907). Москва: Совм. советско-австрийскоепредприятие Х. Г. С.

Моргенштерн, И.Ф. (1903). Психо=Графология. Наука определения внутреннего мира человека по его почерку. (Репринтное воспроизв. изд. 1903). URL: http://moscowwriters.ru/psixgr-mor/pages/1oblozka-psix.htm

Новикова-Грунд, М.В. (2006). Семиотический подход к тексту в рамках культурно-исторической концепции. Вестник РГГУ, 1, 274-303.

Орлова, В.Ф. (2007). Судебно-почерковедческая экспертиза: особенная часть: исследование рукописных текстов. Москва: Наука; РФЦСЭ при Минюсте России. 
Осекова, О.В. (2003). Графологические средства отражения индивидуальнопсихологических особенностей личности. Автореф. дис. канд. психол. наук. Новосибирск: Новосибирский государственный педагогический ун-т.

Сибирская, C. (n.d.). Наклон букв как показатель эмоционального состояния. URL: http://grafol.ru/osnovi/urok-naklon-bukw.html

Сидоренко, Е.В. (2004). Методы математической обработки в психологии. Санкт-Петербург: Речь.

Смыслов, Д.А. (1999). Психологические особенности связей между вербальными и невербальными характеристиками в коммуникативном процессе. Дис. канд. психол. наук. Москва: ГНИИ семьи и воспитания.

Тараненко, В. (2001). Почерк, портрет, характер. Скрытая психодиагностика в практическом изложении. Киев: Ника-Центр.

Турчак, О.М. (2015). Вербальні прояви тривожності у писемному мовленні студентів. Psycholinguistics. Психолінгвістика. Психолингвистика, 18(1), $121-129$.

УЦСЭ: Украинский центр судебных экспетиз. Графологическая експертиза. URL: http://www.ucse.com.ua/expertise/16/

Фомина, Н.А. (2018). Речевая диагностика целостной сущности личности. Psycholinguistics. Психолінгвістика. Психолингвистика, 24(1), 360-380. https://doi.org/10.31470/2309-1797-2018-24-1-360-380

Фомина, Н., \& Орлов, В. (2017). Речевая диагностика особенностей направленности личности подростков. Psycholinguistics. Психолінгвістика. Психолингвистика, 22(1), 208-225. DOI: 10.5281/zenodo.1088406

Фомина, Н.А., \& Мирчетич, М.А. (2013). Лингвистические и психологические характеристики продуктов речевой деятельности студентов с преобладанием первой сигнальной системы. Psycholinguistics. Психолінгвістика. Психолингвистика, 14, 152-163.

Фомина, Н., \& Леева, А. (2013). Проявления индивидуальных особенностей личности в речевой продукции на предтекстовом уровне. Psycholinguistics. Психолінгвістика. Психолингвистика, 12, 140-147.

Чернов, Ю.Г. (2012). Анализ почерка в работе с кадрами. Санкт-Петербург: БХВ.

Шевеленкова, Т.Д., \& Фесенко, П.П. (2005). Психологическое благополучне личности (обзор основних концепций и методика исследования). Психологическая диагностика, 3, 95-130.

Щеголев, И. (2005). 16 типов личности - 16 типов почерка. Санкт-Петербург: Питер.

Biber, D. (1988). Variation Across Speech and Writing. New York, NY: Cambridge University Press. https://doi.org/10.1017/CBO9780511621024

Ben-Shakhar, G., Bar-Hillel, M., Bilu, Y., Ben-Abba, E., \& Flug, A. (1986). Can graphology predict occupational success? Two empirical studies and some methodological ruminations. Journal of Applied Psychology, 71(4), 645-653. https://doi.org/10.1037/0021-9010.71.4.645

Beyond Science? (1997). Show 802: Paper Personality. URL: http://www.cheddangier.com/frontiers/season8.html

Encyclopedia Britannica Online (2011). URL: https:/www.britannica.com/topic/ graphology

Forer, B.R. (1949). The fallacy of personal validation: a classroom demonstration of gullibility. The Journal of Abnormal and Social Psychology, 44(1), 118-123. https://doi.org/10.1037/h0059240 
Gómez-Jiménez, E.. (2015). An Introduction to Graphology: Definition. Theoretical Background and Levels of Analysis, 51, 71-85.

Greasley, P. (2000). Handwriting analysis and personality assessment: The creative use of analogy, symbolism, and metaphor. European Psychologist, 5(1), 44-51. https://doi.org/10.1027//1016-9040.5.1.44

Jansen, A. (1973) Validation of Graphological Judgments: An Experimental Study. Netherlands: Mouton Publishers, The Hague. https://doi. org/10.1515/9783111556499

Jakovljev, I. \& Milin, P. (2017). The relationship between thematic, lexical, and syntactic features of written texts and personality traits. Psihologija, 50(1), 6784. https://doi.org/10.2298/PSI161012006J

John, O.P., Donahue, E.M., \& Kentle, R.L. (1991). The Big Five Inventory - Versions $4 a$ and 54. Berkeley, CA: University of California, Berkeley, Institute of Personality and Social Research. https://doi.org/10.1037/t07550-000

Juola, P. (2006). Authorship Attribution. Foundation and Trends in Information Retrieval, 1(3), 233-334. https://doi.org/10.1561/1500000005

King, R.N., \& Koehler, D.J. (2000). Illusory correlations in graphological inference. Journal of Experimental Psychology, 6(4), 336-348. https://doi.org/10.1037/1076898X.6.4.336

Kress, Gunther (1996). «What is a mode?». In Jewitt, Carey (Ed.), The Routledge Handbook of Multimodal Analysis (pp. 54-67). London: Routledge.

Kress, Gunther, \& Leeuwen, Theo Van. (1996). Reading Images. The Grammar of Visual Design. London: Routledge.

Lennard, J. (2006). The Poetry Handbook. Oxford: Oxford University Press.

Levenston, E.A. (1992). The Stuff of Literature: Physical Aspects of Texts and Their Relation to Literary Meaning. Albany: State University of New York Press.

Mairesse, F., Walker, M.A., Mehl, M.R., \& Moore, R.K. (2007). Using linguistic cues for the automatic recognition of personality in conversation and text. Journal of Artificial Intelligence Research, 30, 457-500. https://doi.org/10.1613/jair.2349

McMenamin, G.R. (2002). Forensic Linguistics: Advances in Forensic Stylistics. CRC Press. https://doi.org/10.1201/9781420041170

Mischel, W., \& Shoda, Y. (1995). A cognitive-affective system theory of personality: reconceptualizing situations, dispositions, dynamics, and invariance in personality structure. Psychological Review, 102(2), 246-268. https://doi.org/10.1037/0033295X.102.2.246

Nkopuruk, Imikan. (2018). Graphological Deviation in Stylistics: Expressions from the Poetry of Joe Ushie. doi: 10.13140/RG.2.2.35976.88325

Rafaeli, A., \& Klimoski, R.J. (1983). Predicting sales success through handwriting analysis: An evaluation of the effects of training and handwriting sample content. Journal of Applied Psychology, 68(2), 212-217. http://dx.doi.org/10.1037/00219010.68.2.212

Rand, H.A. (1947). Graphology: a Handbook. Cambridge: Sci-Art Publishers.

Roback, A.A. (1939). The Psychology of Common Sense: A Diagnosis of Modern Philistinism. Literary Licensing, LLC. https://doi.org/10.1037/11492-000

Sonnemann, U. (1950). Handwriting Analysis as a Psychodiagnostic Tool: a Study in General and Clinical Graphology. Oxford: Grune \& Stratton.

Steiner, D.D., \& Gilliland, S.W. (1996). Fairness reactions to personnel selection techniques in France and the United States. Journal of Applied Psychology, 81(2), 134-141. http://dx.doi.org/10.1037/0021-9010.81.2.134 
Thiry, B. (2009). Exploring the validity of graphology with the Rorschach test. Rorschachiana, 30(1), 26-47. http://dx.doi.org/10.1027/1192-5604.30.1.26

Van Halteren, H., Baayen, H., Tweedie, F., Haverkort, M., \& Neijt, A. (2005). New machine learning methods demonstrate the existence of a human stylome. Journal of Quantitative Linguistics, 12(1), 65-77. https://doi. org/10.1080/09296170500055350

Wright, W.R. (2014). Personality Profiling from Text and Grammar. In: Dimitrova V., Kuflik T., Chin D., Ricci F., Dolog P., Houben G.J. (Eds.), User Modeling, Adaptation, and Personalization. UMAP 2014. Lecture Notes in Computer Science. (Vol. 8538). Springer, Cham, https://doi.org/10.1007/978-3-319-08786-3_47

\section{References}

Bobovkin, M.V., \& Ruchkin, V.A. (2017) Sudebno-pocherkovedcheskaja diagnostika i grafologija: aktualnye voprosy teorii i praktiki [Forensic Handwriting Examination and Graphology: Current Issues of the Theory and Practice]. Pravovaja paradigma - Legal Concept, 16(3), 136-140 [in Russian].

Viskovatova, T.P., \& Nizovcev, N.V. (2008). Opredelenie harakterologicheskih osobennostej podsledstvennogo po pocherku [Determination of the Characterological Features of the Defendant on Handwriting]. Odessa: PNC APN Ukrainy [in Ukrainian].

Volkova, A.H. (2014). Diagnostika dushevnogo stradaniya: psikhologo-lingvisticheskiy analiz pismennogo teksta $\mathrm{v}$ sudebnoy ekspertize [Diagnosis of Mental Suffering: Psycho-Linguistic Analysis of Written Text in Forensic Examination]. Psykholinhvistyka - Psycholinguistics, 16, 203-211 [in Ukrainian].

Vostrikov, E. (2010). Trivialnaja grafologija [Trivial Graphology]. URL: https:// psyfactor.org/lib/grafologia.htm [in Russian].

Goldberg, I. (2012). Grafologija: «Po naklonnoj?» ili sekret naklona pocherka ["On inclined?» Or the secret of the handwriting inclination]. URL: https://psyfactor. org/lib/graphology8.htm [in Russian].

Grafologija - azbuka lichnosti (n.d.). Personalnyj sajt S. Sibirskoj [Graphology - the Alphabet of Personality. Personal Site of S. Siberian)]. URL: http://grafol.ru [in Russian]

Zuev-Insarov, D.M. (1992). Pocherk i lichnost [Handwriting and Personality]. Kyiv: Perlit prodakshn [in Russian].

Kovalev, P.A. (2016). Rol grafologicheskoj teorii v sudebnom pocherkovedenii [Role of Graphological Theory in Forensic Handwriting Analysis]. Istoricheskie, filosofskie, politicheskie $i$ juridicheskie nauki, kulturologija i iskusstvovedenie. Voprosy teorii i praktiki - Historical, Philosophical, Political and Legal Sciences, Culturology and Art Studies. Questions of theory and practice, 4(66), 71-75 [in Russian].

Kravchenko, V.I. (2016). Chelovek v aspektah grafologii: filosofsko-antropologicheskij analiz [The Man in the Aspects of Graphology: Philosophical and Anthropological Analysis]. Vestnik LGU im. A.S. Pushkina - Vestnik LSU named after A.S. Pushkin, 3, 126-132 [in Russian].

Leontev, A.A. (1999). Osnovy psiholingvistiki [Fundamentals of Psycholinguistics]. Moscow: Smysl. 
Linevich, V.L. (1998). Psihofiziologicheskie prediktory diskoordinacii pocherka pri stresse [Psychophysiological Predictors of Handwriting Discovery During Stress]. Candidate's thesis. Ufa: Ufim. fil. fak. psihologii MGU im. M.V. Lomonosova, Ufim. jurid. in-t MVD Rossii [in Russian].

Maksymenko, S., \& Orap, M. (2015). Psykholinhvistychni predyktory zdorovia [Psychology Health Predictors]. Psykholinhvistyka - Psycholinguistics, 18(1), 252-269. https://doi.org/10.31470/2309-1797-2018-24-1-252-268 [in Ukrainian].

Majackij, V. (1990). Grafologija. (Reprintnoe vosproizvedenie izdanija 1907) [Graphology. (Reproduction of the 1907 Edition)]. Moscow: Sovm. sovetskoavstrijskoe predprijatie H. G. S. [in Russian].

Morgenshtern, I.F. (1903). Psiho=Grafologija. Nauka opredelenija vnutrennego mira cheloveka po ego pocherku. (Reprintnoe vosproizvedenie izdanija 1903) [Psycho = Graphology. The Science of Determining the Inner World of Man According to his Handwriting. (Reproduction of the 1903 edition)]. URL: http:// moscowwriters.ru/psixgr-mor/pages/1oblozka-psix.htm [in Russian].

Novikova-Grund, M.V. (2006). Semioticheskij podhod k tekstu v ramkah kulturnoistoricheskoj koncepcii [Semiotic Approach to the Text in the Framework of the Cultural-Historical Concept]. Vestnik RGGU - Bulletin of the RSUH, 1, 274-303 [in Russian].

Orlova, V.F. (2007). Sudebno-pocherkovedcheskaja jekspertiza: osobennaja chast: issledovanie rukopisnyh tekstov [Forensic Handwriting Examination: the Special Part: The Study of Handwritten Texts]. Moscow: Nauka; RFCSJe pri Minjuste Rossii [in Russian].

Osekova, O.V. (2003). Grafologicheskie sredstva otrazhenija individualnopsihologicheskih osobennostej lichnosti [Graphological Means of Reflecting the Individual Psychological Characteristics of a Person]. Extended abstract of candidate's thesis. Novosibirsk: Novosibirskij gosudarstvennyj pedagogicheskij universitet [in Russian].

Sibirskaja, S. (n.d.). Naklon bukv kak pokazatel jemocionalnogo sostojanija [The Slope of the Letters as an Indicator of the Emotional State]. URL: http://grafol.ru/ osnovi/urok-naklon-bukw.html [in Russian].

Sidorenko, E.V. (2004). Metody matematicheskoj obrabotki v psihologii [Methods of Mathematical Processing in Psychology]. Sankt-Peterburg: Rech [in Russian].

Smyslov, D.A. (1999). Psihologicheskie osobennosti svjazej mezhdu verbalnymi i neverbalnymi harakteristikami $\mathrm{v}$ kommunikativnom processe [Psychological Features of the Relationship Between Verbal and Non-Verbal Characteristics in the Communicative Process]. Extended abstract of candidate's thesis. Moscow: Gosudarstvennyj nauchno-issledovatelskij institut sem'i i vospitanija [in Russian].

Taranenko, V. (2001). Pocherk, portret, harakter. Skrytaja psihodiagnostika $v$ prakticheskom izlozhenii [Handwriting, Portrait, Character. Hidden Psychodiagnosis in Practical Terms]. Kyiv: Nika-Centr [in Russian].

Turchak, O.M. (2015). Verbalni proiavy tryvozhnosti u pysemnomu movlenni studentiv [Verbal Manifestations of Anxiety in Student Writing]. Psykholinhvistyka Psycholinguistics, 18(1), 121-129 [in Ukrainian].

UCSJ - Ukrainskij centr sudebnyh jekspetiz [Graphological Examination. Ukrainian Center for Forensic Expeditions]. URL: http://www.ucse.com.ua/expertise/16/ [in Russian].

Fomina, N.A. (2018). Rechevaja diagnostika celostnoj sushhnosti lichnosti [Speech Diagnosis of the Holistic Essence of Personality]. Psykholinhvistyka - 
Psycholinguistics, 24(1), 360-380. https://doi.org/10.31470/2309-1797-2018-24-1360-380 [in Russian].

Fomina, N., \& Orlov, V. (2017). Rechevaja diagnostika osobennostej napravlennosti lichnosti podrostkov [Speech Diagnostics of Personality Traits of Adolescents]. Psykholinhvistyka - Psycholinguistics, 22(1), 208-225. DOI 10.5281/ zenodo.1088406 [in Russian].

Fomina, N.A., \& Myrchetych, M.A. (2013). Lingvisticheskiye i psikhologicheskiye kharakteristiki produktov rechevoy deyatelnosti studentov s preobladaniyem pervoy signalnoy sistemy [Linguistic and Psychological Characteristics of Speech Activity Products of Students With the Domination of the First Signaling System]. Psykholinhvistyka - Psycholinguistics, 14, 152-163 [in Russian].

Fomina, N.A., \& Leieva, A.M. (2013). Proyavleniya identichnosti lichnosti v rechevoy produktsii na predtekstovom urovne [Manifestations of Individual Personality Traits in Speech Products at the Text-Level Level]. Psykholinhvistyka Psycholinguistics, 12, 140-147 [in Russian].

Chernov, Ju.G. (2012). Analiz pocherka v rabote s kadrami [Analysis of Handwriting in the Work with Personnel]. Sankt-Peterburg: BHV-Peterburg [in Russian].

Shevelenkova, T.D., \& Fesenko, P.P. (2005). Psihologicheskoe blagopoluchie lichnosti (obzor osnovnyh koncepcij i metodika issledovanija) [Psychological WellBeing of the Individual (Review of Basic Concepts and Research Methods)]. Psihologicheskaja diagnostika - Psychological Diagnostics, 3, 95-130 [in Russian].

Shhegolev, I. (2005). 16 tipov lichnosti - 16 tipov pocherka [16 Types of Personality 16 Types of Handwriting]. Sankt-Peterburg: Piter [in Russian].

Biber, D. (1988). Variation Across Speech and Writing. New York, NY: Cambridge University Press. https://doi.org/10.1017/CBO9780511621024

Ben-Shakhar, G., Bar-Hillel, M., Bilu, Y., Ben-Abba, E., \& Flug, A. (1986). Can graphology predict occupational success? Two empirical studies and some methodological ruminations. Journal of Applied Psychology, 71(4), 645-653. https://doi.org/10.1037/0021-9010.71.4.645

Beyond Science? (1997). Show 802: Paper Personality. URL: http://www.cheddangier.com/frontiers/season8.html

Encyclopedia Britannica Online (2011). URL: https://www.britannica.com/topic/graphology

Forer, B.R. (1949). The fallacy of personal validation: a classroom demonstration of gullibility. The Journal of Abnormal and Social Psychology, 44(1), 118-123. https://doi.org/10.1037/h0059240

Gómez-Jiménez, E.. (2015). An Introduction to Graphology: Definition. Theoretical Background and Levels of Analysis, 51, 71-85.

Greasley, P. (2000). Handwriting analysis and personality assessment: The creative use of analogy, symbolism, and metaphor. European Psychologist, 5(1), 44-51. https://doi.org/10.1027//1016-9040.5.1.44

Jansen, A. (1973) Validation of Graphological Judgments: An Experimental Study. Netherlands: Mouton Publishers, The Hague. https://doi. org/10.1515/9783111556499

Jakovljev, I. \& Milin, P. (2017). The relationship between thematic, lexical, and syntactic features of written texts and personality traits. Psihologija, 50(1), 6784. https://doi.org/10.2298/PSI161012006J

John, O.P., Donahue, E.M., \& Kentle, R.L. (1991). The Big Five Inventory - Versions $4 a$ and 54. Berkeley, CA: University of California, Berkeley, Institute of Personality and Social Research. https://doi.org/10.1037/t07550-000 
Juola, P. (2006). Authorship Attribution. Foundation and Trends in Information Retrieval, 1(3), 233-334. https://doi.org/10.1561/1500000005

King, R.N., \& Koehler, D.J. (2000). Illusory correlations in graphological inference. Journal of Experimental Psychology, 6(4), 336-348. https://doi.org/10.1037/1076898X.6.4.336

Kress, Gunther (1996). «What is a mode?». In Jewitt, Carey (Ed.), The Routledge Handbook of Multimodal Analysis (pp. 54-67). London: Routledge.

Kress, Gunther, \& Leeuwen, Theo Van. (1996). Reading Images. The Grammar of Visual Design. London: Routledge.

Lennard, J. (2006). The Poetry Handbook. Oxford: Oxford University Press.

Levenston, E.A. (1992). The Stuff of Literature: Physical Aspects of Texts and Their Relation to Literary Meaning. Albany: State University of New York Press.

Mairesse, F., Walker, M.A., Mehl, M.R., \& Moore, R.K. (2007). Using linguistic cues for the automatic recognition of personality in conversation and text. Journal of Artificial Intelligence Research, 30, 457-500. https://doi.org/10.1613/jair.2349

McMenamin, G.R. (2002). Forensic Linguistics: Advances in Forensic Stylistics. CRC Press. https://doi.org/10.1201/9781420041170

Mischel, W., \& Shoda, Y. (1995). A cognitive-affective system theory of personality: reconceptualizing situations, dispositions, dynamics, and invariance in personality structure. Psychological Review, 102(2), 246-268. https://doi.org/10.1037/0033295X.102.2.246

Nkopuruk, Imikan. (2018). Graphological Deviation in Stylistics: Expressions from the Poetry of Joe Ushie. doi: 10.13140/RG.2.2.35976.88325

Rafaeli, A., \& Klimoski, R.J. (1983). Predicting sales success through handwriting analysis: An evaluation of the effects of training and handwriting sample content. Journal of Applied Psychology, 68(2), 212-217. http://dx.doi.org/10.1037/00219010.68.2.212

Rand, H.A. (1947). Graphology: a Handbook. Cambridge: Sci-Art Publishers.

Roback, A.A. (1939). The Psychology of Common Sense: A Diagnosis of Modern Philistinism. Literary Licensing, LLC. https://doi.org/10.1037/11492-000

Sonnemann, U. (1950). Handwriting Analysis as a Psychodiagnostic Tool: a Study in General and Clinical Graphology. Oxford: Grune \& Stratton.

Steiner, D.D., \& Gilliland, S.W. (1996). Fairness reactions to personnel selection techniques in France and the United States. Journal of Applied Psychology, 81(2), 134-141. http://dx.doi.org/10.1037/0021-9010.81.2.134

Thiry, B. (2009). Exploring the validity of graphology with the Rorschach test. Rorschachiana, 30(1), 26-47. http://dx.doi.org/10.1027/1192-5604.30.1.26

Van Halteren, H., Baayen, H., Tweedie, F., Haverkort, M., \& Neijt, A. (2005). New machine learning methods demonstrate the existence of a human stylome. Journal of Quantitative Linguistics, 12(1), 65-77. https://doi. org/10.1080/09296170500055350

Wright, W.R. (2014). Personality Profiling from Text and Grammar. In: Dimitrova V., Kuflik T., Chin D., Ricci F., Dolog P., Houben G.J. (Eds.), User Modeling, Adaptation, and Personalization. UMAP 2014. Lecture Notes in Computer Science. (Vol. 8538). Springer, Cham, DOI: https://doi.org/10.1007/978-3-31908786-3_47 


\section{АНОТАЦІЯ}

Вступ. Стаття містить критичний аналіз графологічного підходу до вивчення рукописних текстів. Постановка проблеми обгрунтована особливим шляхом формування вітчизняної психології, яка довгий час була ізольованою від світових тенденцій. Хоча вивчення рукописів не є поширеною практикою, психолінгвістичний графологічний аналіз визнається на найвищому академічному рівні, в тому числі в сфері судочинства. Метою дослідження $\epsilon$ емпірична перевірка психолінгводіагностичного потенціалу почерку як продукту мовленнєвої діяльності особистості.

Процедура дослідження. Об'єктом емпіричної перевірки виступає лівосторонній нахил як відхилення від звичайного способу письма. Зібрано дані про варіативність змінної у вибірці 119 студентів. На основі кластеризації виділені три дослідницькі групи: з лівостороннім, прямим та правостороннім почерком. Результати. Вивчені інтерпретації лівостороннього нахилу в керівництвах з графології; показана відсутність еволюції уявлень. З'ясовано, що описи представляють собою філософствування навколо раніше опублікованих текстів з додаванням деталей, власних асоціацій автора; при цьому характеристики почерку антроморфізуються та безпосередньо переносяться на характеристики особистості. Розроблена анкета для перевірки ефекту персональної валідації. Стосовно 40\% тверджень анкети усі респонденти висловилися позитивно, ці формулювання не диференціюють опитаних і не мають діагностичної цінності. Жодна з графологічних інтерпретацій лівого нахилу не виявилася дійсно виразнішою у групі з лівостороннім почерком. За показниками Шкали психологічного благополуччя К. Ріфрф виявлені два випадки статистично значущої різниці між групами з різним почерком: шкали "Управління середовищем» та «Баланс аректу». Отримані результати призводять до думки, що почерк певною мірою концентрує в собі особистісні властивості виконавця $i \epsilon$ інформативною психологічною ознакою - алеця інтерпретація має бути підтверджена даними психолінгвістичного методу. В цілому дослідження демонструє, що почерк може виступати предметом психолінгвістичного дослідження, до якого застосовні визнані в сучасній психології й психолінгвістиці методологічні процедури.

Ключові слова: графологія, психолінгвістичний аналіз почерку, мовна особистість, персональна валідація.

\section{Бочелюк Виталий, Панов Никита \& Валентина Зайцева. Верификация психодиагностических возможностей рукописных текстов}

\section{АННОТАЦИЯ}

Вступление. Статья содержит критический анализ графологического подхода к изучению рукописных текстов. Постановка проблемы обоснована особым путем формирования отечественной психологии, которая долгое время была изолирована от мировых тенденций. Хотя изучение рукописей не является распространенной практикой, психолингвистический графологический 
анализ признан на высшем академическом уровне, в том числе в сфрере судопроизводства. Целью исследования является эмпирическая проверка психолингводиагностического потенциала почерка как продукта речевой деятельности личности.

Процедура исследования. Объектом эмпирической проверки выступает левосторонний наклон как отклонение от обычного способа письма. Собраны данные о вариативности переменной в выборке 119 студентов, в процессе кластеризации выделены три исследовательские группы: с левосторонним, прямым и правосторонним почерком.

Результаты. Изучены интерпретации левостороннего наклона в руководствах по графологии, показано отсутствие эволюции представлений. Определено, что описания представляют собой философствования вокруг ранее опубликованных текстов с добавлением деталей, собственных ассоциаций автора; при этом характеристики почерка антроморфизируються и непосредственно переносятся на характеристики личности. Разработана анкета для проверки эфректа персональной валидации. Относительно 40\% утверждений анкеты все респонденты высказались положительно, эти формулировки не дифференцируют опрошенных и не имеют диагностической ценности. Ни одна из графологических интерпретаций левого наклона не оказалась действительно преобладающей в группе с левосторонним почерком. При использовании Шкалы психологического благополучия К. Рифрф обнаружены два случая статистически значимой разницы между группами с разным почерком: шкалы "Управление средой» и "Баланс аффректа». Полученные результаты приводят к мысли, что почерк в определенной степени концентрирует в себе личностные свойства исполнителя и является информативным психологическим признаком - но эта интерпретация должна быть подтверждена данными психолингвистического метода. В целом исследование показывает, что почерк может выступать предметом психолингвистического исследования, к которому применимы признанные в современной психологии и психолингвистике методологические процедуры.

Ключевые слова: графология, психолингвистический анализ почерка, языковая личность, персональная валидация. 